\title{
Erratum to: The serum CXCL13 level is associated with the Glasgow Prognostic Score in extranodal NK/T-cell lymphoma patients
}

Seok Jin Kim ${ }^{1,5}$, Kyung Ju Ryu ${ }^{2}$, Mineui Hong ${ }^{3}$, Young Hyeh Ko ${ }^{4}$ and Won Seog Kim ${ }^{1 *}$

Unfortunately, the original version of this article [1] contained an error. The legend for Table 2 was included incorrectly. The corrected legend is 'The association of CXCL13 with unfavourable parameters'.

\begin{abstract}
Author details
'Division of Hematology and Oncology, Department of Medicine, Samsung Medical Center, Sungkyunkwan University School of Medicine, Seoul, Korea.

${ }^{2}$ Samsung Biomedical Research Institute, Samsung Medical Center, Seoul, Korea. ${ }^{3}$ Department of Pathology, Kangnam Sacred Heart Hospital, Hallym University, Seoul, Korea. ${ }^{4}$ Department of Pathology, Samsung Medical Center, Sungkyunkwan University School of Medicine, Seoul, Korea. ${ }^{5}$ Department of Health Sciences and Technology, SAIHST, Sungkyunkwan University School of Medicine, Seoul, Korea.
\end{abstract}

Received: 27 July 2015 Accepted: 17 August 2015

Published online: 08 October 2015

\section{Reference}

1. Kim SJ, Ryu KJ, Hong M, Ko YH, Kim WS. The serum CXCL13 level is associated with the Glasgow Prognostic Score in extranodal NKT-cell lymphoma patients. J Hematol Oncol. 2015;8:49.

\footnotetext{
* Correspondence: wskimsmc@skku.edu

'Division of Hematology and Oncology, Department of Medicine, Samsung Medical Center, Sungkyunkwan University School of Medicine, Seoul, Korea
}

Full list of author information is available at the end of the article

\section{Submit your next manuscript to BioMed Central and take full advantage of:}

- Convenient online submission

- Thorough peer review

- No space constraints or color figure charges

- Immediate publication on acceptance

- Inclusion in PubMed, CAS, Scopus and Google Scholar

- Research which is freely available for redistribution 